\title{
NATIONALISM, THE IRISH CONSTITUTION, AND MULTICULTURAL CITIZENSHIP
}

\author{
Desmond M Clarke, Associate Professor of Philosophy, \\ University College Cork
}

"One thing that can be said about the Constitution is that it is a nationalist constitution."

This comment, which occurs in Barrington J's judgment in McGimpsey v Ireland, was made as if it were a completely uncontentious and agreed description of the Irish Constitution, in a context where widely divergent interpretations of the text were being reviewed as a prelude to giving a judgment. The very obviousness with which it was asserted suggests a need to analyse what is meant by describing a constitution as "nationalist," and to clarify its implications, if any, for our understanding of Irish citizenship.

Such an analysis is greatly facilitated by recent work on nationalism. These studies were motivated, to some extent, by the emergence of nationalist claims in many countries worldwide, including the former Yugoslavia and former Soviet republics. For critics, such as Michael Ignatieff, there is much in contemporary manifestations of Romantic nationalism to be regretted or condemned. ${ }^{2}$ But condemnation or regret is not enough; one also needs to understand a phenomenon which has even a fraction of the political influence that is attributed to nationalism. Hence the renewed interest among political scientists and philosophers in analysing what we mean by "nations" or "national identity," and in re-assessing the meaning and validity of the claim that nations or national groups have distinctive political rights.

In Part I, I borrow on the results of this recent work and identify some of the defining features of a nationalist ideology. In Part II, I apply this analysis to the Irish Constitution, and make explicit some of its nationalist assumptions. Finally, in Part III, I examine whether nationalism precludes the emergence of other equally important issues in the discussion of constitutional arrangements at the beginning of a new millennium. In particular, is the apparent dominance of nationalist identities a hindrance to recognising the reality of multicultural citizenship, and the need to create political structures which could more adequately reflect that reality? ${ }^{3}$ I argue that one widely accepted concept of nationalism, which seems to be endorsed by the Irish Constitution, over-simplifies the conceptual framework in which we currently discuss constitutional arrangements in Ireland, and thereby obstructs other equally important realities from being adequately acknowledged or considered.

McGimpsey v Ireland [1988] I R 567, at p 583.

2 Ignatieff, Blood and Belonging: Journeys into the New Nationalism (1994).

3 Yael Tamir has articulated this issue, about seeing some realities so clearly that others are obscured or ignored, in "The Age of Atonement," Clarke and Jones, eds. The Rights of Nations (1999), pp 88-99. 


\section{PART I - MODERN NATIONALISM}

One of the key features of nationalist thinking is the idea that many different individuals, in different historical periods and perhaps even in different geographical regions, form a single people. The unique identity of the people is explained partly by reference to a common culture, shared traditions, linguistic uniformity, perhaps even the same religious beliefs. A model for this trans-temporal unity was provided by the Biblical account of the Jews as a chosen people who, despite their lengthy diaspora, preserved a belief in their distinctive identity and in their divinely ordained destiny to return to a chosen land. ${ }^{4}$ In fact, the Biblical paradigm provides a model for a number of features that are found in modern, secular versions of nationalism. Smith identifies four such features: (i) the ideal of ethnic election, of being a chosen or special people in some sense; (ii) the idea of a sacred or distinctive history, usually associated with a particular geographical territory; (iii) the memory of a golden age, a return to which or a recovery of which helps motivate many modern nationalists; and (iv) the importance of acts of commemoration, especially of the glorious dead who gave their lives for the sake of the people. ${ }^{5}$

Implicit in the features just mentioned is the role played by the beliefs of a given community about itself, the shared beliefs of a large number of individuals in virtue of which they think of themselves as having a common identity and, therefore, as having certain moral and political rights and responsibilities towards each other. This implies that the mere fact that people speak the same language, worship the same God, inhabit a given geographical territory, and so forth would not be sufficient to constitute them as a single people or nation. In the phrase used by Benedict Anderson, a nation is an "imagined community." Anderson does not mean that nations are imaginary or unreal; rather, he claims that "the members of even the smallest nation will never know most of their fellow-members, meet them, or even hear of them, yet in the minds of each lives the image of their communion." In other words, the unity of the nation is an imaginative construction on the part of its members, even if the possibility of maintaining such a construction presupposes at least some of the common cultural features that nations typically exhibit. A similar point is made by David Miller: "national communities are constituted by belief; nations exist when their members recognize one another as compatriots, and believe that they share characteristics of the relevant kind."7 This suggests that certain commonly held 'beliefs' are a necessary condition for national identity.

${ }^{4}$ See especially the writings of Anthony D. Smith, The Ethnic Origins of Nations (1986); Nations and Nationalism in a Global Era (1995); Nationalism and Modernism (1998).

5 These are summarised in Smith, 'Social and Religious Origins of Nations,' in D Clarke and C Jones, eds, p 26.

6 Anderson, Imagined Communities (1983), p 6.

7 Miller, On Nationality (1995), p 22. 
Without them, we merely have a population of individuals who happen to have various objective features in common. ${ }^{8}$

If national identity cannot be established simply by the colour of one's skin, the place of one's birth, one's maternal language[s], or other similarly objective features, it suggests that there is more flexibility than might otherwise be expected in the imaginative construction involved in developing a national consciousness. I return to this issue later. The role of beliefs in nation-building also raises a question about the motivation or rationale for making distinctions between nations, for treating some people as being conationals and others as not - assuming that everyone in the world is not equally a member of a single nation. There are a number of different comments worth making here, depending on what kind of nationalism is at issue. One reason for cultivating the concept of a nation, in the eighteenth century, was a rejection of the divine right of kings and the relocation of political authority in "the people". Evidently, the identity of "the people" in question varied with the context in which the political change took place. In the political theory inspired by John Locke, the argument proposed was that the authority of any legislature originates in the consent of individuals who conditionally surrender some of their natural rights to the legislature. These rights do not derive from the commonwealth; on the contrary, the limited powers and jurisdiction of the commonwealth derive from "the people". Similarly, in the first constitution which followed the French Revolution, one finds a republican expression of the role of the nation or people as the exclusive source of all political authority: "The principle of all sovereignty resides essentially in the Nation. No body, no individual can exercise any authority that does not issue explicitly from the Nation." 9 In these cases, nationality emerges as one dimension in the development of popular democracy, even if it remains unclear who "the people" are and how one is expected to demarcate its membership. ${ }^{10}$

One of the most well-known insights into the dynamics of modern nationalism, first articulated by Ernest Gellner, is that nations typically aspire to statehood. "Nationalism is primarily a political principle, which holds that the political and the national unit should be congruent. . . . Nationalism is a theory of political legitimacy, which requires that ethnic [does he mean national?] boundaries should not cut across political ones, and, in particular, that ethnic boundaries within a given state . . . should not separate the powerholders from the rest". ${ }^{11}$ One could gloss for the moment over Gellner's conflation of ethnic and national identity. In the language of nations, his suggestion is that modern nationalism is motivated by the belief that each

$8 C f$ Lord Fraser's interpretation of an ethnic group, in the context of antidiscrimination legislation (the Race Relations Acts 1972), in Mandla v Dowell Lee [1983] 2 AC 548, at 562.

9 French Constitution of 1791 , Article 3.

10 Recent discussions of Scottish nationalism and of the type of autonomy in selfgovernment which would adequately express its democratic inspirations are relevant here. $C f$ the Scotland Act 1998; R. Brazier, "The Constitution of the United Kingdom," [1999] CLJ 96; G. Clark, "Scottish Devolution and the European Union" Public Law [1999] 504.

11 Gellner, Nations and Nationalism (1983), p 1. 
distinctive national group is entitled to govern itself in a separate state or a comparable political unit.

This might suggest that nations normally pre-exist the alleged dynamic to become a separate state. But Gellner has also argued that nationalism often comes first and creates both nations and states. Linda Colley has documented this argument for Britain in the eighteenth and nineteenth centuries, when British nationalism was explicitly cultivated as a means to state-building. ${ }^{12}$ The kind of nationalism that was espoused by Thomas Davis in The Nation, in nineteenth-century Ireland, can likewise be compared with contemporaneous proposals in Germany, Italy or elsewhere in Europe. Thus while already existing nations may aspire to become autonomous states, it seems equally clear in some cases that governments or political leaders cultivate a national consciousness as a means to consolidating the unity of disparate regions and cultural communities in a single state, or of generating political support for the creation of a new state.

Whether nations evolve into states or states cultivate nationalism to provide political unity in times of crisis or transition, it is widely assumed that nations have a right to self-determination. This is reflected, for example, in the fact that Article 1 of two United Nations Covenants, the International Covenant on Economic, Social and Cultural Rights and the International Covenant on Civil and Political Rights both begin with exactly the same provision:

"1. All peoples have the right to self-determination. By virtue of that right they freely determine their political status and freely pursue their economic, social and cultural development".

Many commentators have struggled to provide a theoretical account of what is meant by "peoples" and "self-determination" here. ${ }^{13}$ In this context, Yael Tamir has drawn attention to a basic distinction between: (a) the democratic government of a given community of people; and (b) the government of a given community by [some of] its own members. The former implies that the members of the community have a genuine input into the way in which they are governed, even if those who govern them are not members of the same community but are, for example, elected representatives in a federal parliament (such as the European Parliament). In contrast, (b) merely stipulates that those who govern a community must be members of the same community, and this may be realised even by a dictatorship within the same community or nation. ${ }^{14}$

Evidently, nationalism may be presented today as an expression of these two radically different projects. In the former, we claim that political power derives from the people who choose to be governed in a certain way; in the latter, we claim that a group of people, as such, is identifiable as a distinct nation which has a legitimate claim to autonomous government. There are

12 See Colley, Britons: Forging the Nation 1707-1837 (1996).

13 See for example, Freeman, 'The Right to National Self-Determination,' in Clarke and Jones, eds, $45 \mathrm{ff}$ and Raz and Margalit, "National Self-Determination," in Raz, Ethics and the Public Domain (1994), 125.

14 Tamir, Liberal Nationalism (1993), p 71. 
also degrees of autonomy; at the limit, this form of nationalism demands a separate, sovereign state for each distinct national group.

Given the historical connection between cultivating nationalism as a means of state-building, and claiming sovereign statehood for a people and region that claims to be a nation, it is important in contemporary discussions not to collapse the terms "nation" and "state" into synonyms. ${ }^{15}$ Such a semantic conflation precludes making distinctions that are necessary and asking questions, especially about the warrant for various political claims, that need to be asked.

Finally, one of the most contentious assumptions of nationalism is the apparent homogeneity that is often implicit in speaking about a single people or a nation. One may be tempted to lay the blame here on German Romanticism, or on similar philosophies which attributed a quasi-spiritual unity to a large population of people despite the reality of their obvious differences. This is not merely a philosophical or academic dispute between hard-nosed realists and romantic idealists. Failure to address this issue explicitly has the effect either of excluding some people from membership of a given nation - because they fail to satisfy some criterion that is often implicit and unnecessary - or of including individuals of very different cultural traditions within the same nation, without their consent, and then demanding that they adopt the culture of those who see themselves as paradigm representatives of "the nation".

In this context, nationalism can exhibit a form of cultural blindness which fails to recognise the reality of multiculturalism. ${ }^{16}$

It is clear from the literature that there is no single phenomenon called nationalism that can be neatly defined by necessary and sufficient conditions. However, one might still anticipate that some or all of the following features are typical of modern forms of nationalism:

a) a belief in the unity and distinctness of a people across generations and geographical boundaries;

b) the assumption that political authority derives ultimately from the people, who have a right to choose their own style of government;

c) a tendency to assume that each nation should enjoy autonomy in selfgovernment; at the limit, each nation should have a separate state and, in general, the boundaries of states should coincide with the geographical distribution of peoples or nations;

15 Cf Lord Simon in Ealing London Borough Council v Race Relations Board [1972] AC 342, 363-4, where the same distinction was required to implement race relations law. "'Nation' and 'national,' in their popular in contrast to their legal sense, are also vague terms. They do not necessarily imply statehood. Scotland is not a nation in the eye of international law, but Scotsmen constitute a nation by reason of those most powerful elements in the creation of national spirit tradition, folk memory, a sentiment of community."

16 The most well-known exponent of this issue in recent political philosophy is Kymlicka. See for example Multicultural Citizenship (1995). 
d) a belief in the cultural homogeneity of members of each nation, or of the relative insignificance of multiculturalism as a challenge to assumptions about the shared features of members of the same nation.

\section{PART II - NATIONALISM IN THE IRISH CONSTITUTION}

It is not a novel thesis to suggest that the Irish Constitution was drafted in an historical context which was significantly influenced by a somewhat uncritical and exclusive form of nationalism, and that the key personality in the drafting process was attempting to combine legal practicalities with symbolic expressions of a distinctive reading of Irish history. ${ }^{17}$ The question being raised here is not an historical one about the way in which the Constitution was drafted, or about the political forces that affected its nationalist character. The issue here is to draw out the implications to which we are committed today by the nationalism of the Constitution. As long as it remains, unamended, as the basic law of the state called "Ireland", we need to make explicit the view of ourselves that it projects to the international community and, in particular, to those who live in Northern Ireland and who are willing to review relations between the neighbouring jurisdictions.

To what extent, therefore, is the Constitution inspired by, or expressive of, a form of nationalism that may no longer represent the views of the majority of citizens of Ireland, and that may exacerbate rather than help resolve recent political problems on the island of Ireland?

The Preamble of the Constitution introduces the nationalist inspiration of the whole document. It refers to both the "nation" and the "people of Ireland", and also includes a prototypical commemoration of the glorious dead whose efforts contributed to the political freedoms that are claimed in the Constitution itself.

"We, the people of Éire, humbly acknowledging all our obligations to our Divine Lord, Jesus Christ, who sustained our fathers through centuries of trial, gratefully remembering their heroic and unremitting struggle to regain the rightful independence of our Nation [Náisiún], and seeking to promote the common good, ... so that . . . the unity of our country [tir $]$ [may be] restored, and concord established with other nations [náisiúin eile], Do hereby adopt, enact, and give to ourselves this Constitution." 18

If one studies the rhetoric and style of nationalist manifestos, one could hardly improve on the clarity with which these opening lines enunciate a belief in a unique people that has reached a turning point in its history at which, due to the heroic deeds of earlier generations, it can adopt a constitution that expresses its distinctive and independent political character. The Irish nation comes of age and asserts its claim to independent statehood.

17 See O'Halloran, Partition and the Limits of Irish Nationalism (1987). For the nationalist dimension of the pre-partition period, see Bew, Ideology and the Irish Question (1994).

18 Given the implications of Article $25,5,4^{\circ}$, to the effect that the Irish text is definitive, I have quoted in parentheses the Irish equivalent of some significant terms. 
However, despite the apparent clarity of the text, there are ambiguities even here in the Preamble. For present purposes, one might simply note the identity of those who claim to enact the Constitution. "We, the people of Éire [muintir na hÉireann] . . . Do hereby adopt, enact, and give to ourselves this Constitution." Who are muintir na hÉireann? Article 4 specifies that 'Ére' [even in the English-language text] is the name of the state which came into being with the enactment of the Constitution and which was formerly called Saorstát Éireann. ${ }^{19}$ Since the vote to enact the Constitution was a majority decision by those who were registered in what was then called the Irish Free State, it is consistent both with the reality of that particular referendum and with the legal implications of Article 4 to suggest that the "people of Éire" mentioned in the Preamble are not identical with the Irish nation, but with the citizens of the Irish Free State who claimed to speak on its behalf.

Nation and State: The term 'nation' is used ten times in the Constitution, and the extent to which it is often confused, in the text, with the term 'state' has already been documented. ${ }^{20}$ This ambiguity in the Constitution has been repeated by the courts, even in cases in which the legal status of the nation or state was at issue. The semantic ambiguity is symptomatic of the nationalist theory which is so pervasive in the text of the Constitution that it slips almost imperceptibly from "nation" to "state" and back again. One of the clearest cases of this terminological variation is in Article 29, which is preceded by the heading: "International Relations". ${ }^{21}$ In section 1, "Ireland [that is, the state called Ireland/Éire] affirms its devotion to the ideal of peace and friendly co-operation amongst nations. ..." In principle, this might be understood as a willingness to recognise other nations, such as the Kurdish nation, which were not legally established as states. But section 3 clarifies that Article 29 is concerned with other states: "Ireland accepts . . . international law as its rule of conduct in its relations with other States." And while the executive power of the State is to be exercised by the Government in external relations (Article 29, $4,1^{\circ}$ ), the Government is authorised by the subsequent sub-section (sec. $4,2^{\circ}$ ) to use a variety of organs, instruments or methods which are adopted by "any group or league of nations with which the State is or becomes associated." Admittedly, the confusion here is no more blatant than in the title of the United Nations, of which only states or their legal equivalent (rather than nations) are eligible for membership. However, in a constitution which recognises a distinct identity for the Irish nation - and in which the Irish term "náisiún" is usually capitalised when denoting the Irish nation ${ }^{22}$ - it requires some explanation as to why the text should oscillate between "nation" and "state" even within the same article.

19 "The name of the State is Éire, or in the English language, Ireland."

20 Clarke, "Nation, State and Nationality in the Irish Constitution" (1998) 16 ILT 252.

21 This is also the article which was amended by the Nineteenth Amendment of the Constitution Act 1998, following the Good Friday Agreement. See below, note 33.

22 For example, in Articles $13.7 .2^{\circ}$ or $41.1 .2^{\circ}$. 


\section{The Nation in Articles 1- 3}

The first three articles of the Constitution are the only ones included under the heading "The Nation". It has often been pointed out that they are not exclusively legal provisions in the narrow sense, but expressions of a political philosophy or of political aspirations which were widely accepted in 1937. This view was expressed by O'Higgins, CJ in In re Article 26 and the Criminal Law (Jurisdiction) Bill, 1975:

"One of the theories held in 1937 by a substantial number of citizens was that a nation, as distinct from a State, had rights; that the Irish people living in what is now called the Republic of Ireland and in Northern Ireland together formed the Irish Nation; that a nation has a right to unity of territory in some form, be it as a unitary or federal state; and that the Government of Ireland Act 1920, though legally binding, was a violation of that national right to unity which was superior to positive law. This national claim to unity exists not in the legal but in the political order and is one of the rights which was envisaged in Article 2". ${ }^{23}$

O'Higgins CJ raises a number of issues in this paragraph. For present purposes it is enough to acknowledge that, in this judgment, the Supreme Court accepted that the Constitution not only established the fundamental law of the State, but that it also expressed political theories that were widely accepted at the time of its enactment. One of those theories was a form of nationalism. This is evident in Article 1:

"The Irish Nation [náisiún na hÉireann] hereby affirms its inalienable, indefeasible, and sovereign right to choose its own form of Government, to determine its relations with other nations [náisiúin], and to develop its life, political, economic and cultural, in accordance with its own genius and traditions."

The classification of this right as "inalienable" suggests that it belongs to the same genre as the "inalienable and imprescriptible rights, antecedent and superior to positive law" that are attributed to the family in Article 41, 1, ${ }^{\circ}$, or the "inalienable right ... of parents to provide ... for the religious and moral . . . education of their children," (Article 42, 1). In other words, it derives from a natural law philosophy which accepts that individuals or groups of individuals have certain natural rights which are prior to their legal acknowledgement in a given jurisdiction. Thus the natural right of the Irish Nation is affirmed or assumed rather than established by Article 1; the justification for the underlying philosophy lies elsewhere.

Articles 2 and 3 are, by now, perhaps the best known in the whole text. Together, they make three references to the "national territory". ${ }^{24}$ This raises a query about what is meant by "national" in this context. The adjective "national" is used sixteen times in the Constitution, and on many occasions it simply means "of or pertaining to the State [rather than the nation]". For

23 [1977] IR 129, at p 147.

24 There are two references in the English text, and three in the Irish version (as $n a$ críocha náisiúnta). 
example, Article 6 refers to "national policy" where it means the policy of the state, and Article 15 (1) mentions the "National Parliament" when the reference is unambiguously to the parliament of the State. However, the Constitution also refers to "the national language" [an teanga náisiúnta] and, while recognising both English and Irish as "official" languages of the state (Article $25,4,6^{\circ}$ ), it classifies Irish as "the national language" and the "first official language". ${ }^{25}$ Thus there is a distinction between being a language recognised in the state as an official language, and the special status of one official language which is legally established as the traditional language of the nation. This has obvious implications for those members of the nation who do not speak Irish, including many of those who were acknowledged in the Preamble as having engaged in an "heroic and unremitting struggle". This is an issue to which I return later. On the evidence available, the term "national" is probably used in Article 25 to mean "of or pertaining to the nation".

Although the use of the term "national" is arguably unclear in some places in the Constitution, there is no ambiguity in Articles 2 and 3, where "national" certainly does not denote the State called Éire/Ireland. Article 2 says that "the national territory consists of the whole island of Ireland", while Article 3 limits the jurisdiction of the state for which the Constitution is the basic law to the same geographical area as the former Saorstát Éireann, that is, the twenty-six counties:

"Pending the re-integration of the national territory [na críocha náisiúnta], and without prejudice to the right of the Parliament and Government established by this Constitution to exercise jurisdiction over the whole of that territory, the laws enacted by that Parliament shall have the like area and extent of application as the laws of Saorstát Éireann and the like extraterritorial effect".

This is a paradigm expression of a nationalist philosophy, or of what Gellner prefers to call an ideology; it claims that there is a national territory over which the Oireachtas has a "right. . . to exercise jurisdiction", although the geography of the island alone could not possibly decide the disputed issue of the rightful jurisdiction of the "Parliament and Government established by this Constitution."

Having expressed these nationalist claims or aspirations in the first three articles of the Constitution, it remained for the courts to interpret their legal effect. On this, the courts have been neither clear nor consistent. In Boland v An Taoiseach, the court rejected a challenge to the constitutionality of the Sunningdale Agreement. ${ }^{26}$ In the course of explaining their decisions, O'Keeffe $\mathrm{J}$ argued that it would have been ultra vires for an Irish Government to have agreed that "the State does. . . not claim to be entitled as of right to jurisdiction over Northern Ireland," and Budd J interpreted

25 Article 8, sec.1; see also Article $25,4,6^{\circ} ; 25,5,4^{\circ}$. In the last two cases, the term corresponding to "national language" in the Irish text is simply Gaeilge. The limited jurisprudence on this topic is summarized in Nic Shuibhne, "The Constitution, the Courts, and the Irish Language," in Murphy and Twomey, eds, Ireland's Evolving Constitution 1937-1997 (1998), pp 253-63.

26 [1974] IR 338. 
Sunningdale as merely an expression of "policy" on the part of the State rather than an "agreement as to the future of Northern Ireland". ${ }^{27}$ In a subsequent case, Russell v Fanning, the Supreme Court considered the extradition of an accused person to Northern Ireland, and rejected an appeal based on the alleged political nature of the offence with which he was charged. In the course of its judgment the Court introduced the term "constitutional imperative" into its understanding of Article 3. Hederman J argued that the "unification of the national territory. . . is. . . a constitutional imperative and not one the pursuit or non-pursuit of which is within the discretion of the government or any other organ of State". ${ }^{28}$ McCarthy $\mathrm{J}$, in his minority opinion in the same case, preferred to interpret the Preamble and Articles 2 and 3 as expressing "a national aspiration". ${ }^{29}$ However, he linked this aspiration with the provisions of Article 6,1:

"All powers of government, legislative, executive and judicial, derive, under God, from the people, whose right it is to designate the rulers of the State and, in final appeal, to decide all questions of national policy [beartas an Náisiúin], according to the requirements of the common good."

While conceding that national policy could not be decided by the courts, McCarthy J concluded that "the people, in final appeal, must decide all questions of national policy.... The Constitution provides but one means of ascertaining the will of the people on such a question." 30 It seems questionable to argue that the Constitution provides only one way of finding out the will of the people; the implication of his remarks seems to be that even an aspiration, once expressed in the Constitution, cannot be changed except by means of a constitutional referendum.

These earlier decisions were summarised in the High Court by Barrington $\mathbf{J}$ in McGimpsey v Ireland, in which the constitutionality of the Anglo-Irish Agreement 1985 was challenged. The High Court decided that the claim about "the national territory" in Article 2 "exists in the political and not in the legal order". ${ }^{31}$ However, the Supreme Court on appeal decided not to follow the interpretation of the High Court and decided instead that Article 2 represented a "claim of legal right" about the extent of the national territory, and that Article 3 expressed a constitutional imperative for its eventual reintegration.

“. . I I am satisfied that the true interpretation of these constitutional provisions is as follows:

1. The reintegration of the national territory is a constitutional imperative ( $c f$. Hederman $\mathbf{J}$ in Russell $\mathrm{v}$ Fanning [1989] ILRM 333).

27 Ibid, 363, and 366-7. Walsh J repeated this interpretation, that the government had expressed "nothing more than a declaration of policy" in Sunningdale, in Crotty v An Taoiseach [1987] IR 713, at p 779.

28 Russell v Fanning [1988] IR 505, at 537.

29 Ibid, p 553.

30 Ibid, p 554.

31 [1988] IR 567, at p 584. 
2. Article 2 of the Constitution consists of a declaration of the extent of the national territory as a claim of legal right.

There can be no doubt but that the only reasonable interpretation of Article 1, taken in conjunction with the denial of derogation from sovereignty contained in Article 2(b) of the Anglo-Irish Agreement, is that it constitutes a recognition of the de facto situation in Northern Ireland but does so expressly without abandoning the claim to the reintegration of the national territory". ${ }^{32}$

It is not clear what "a claim of legal right" means here. The use of the term "claim" suggests that Article 2 involves a claim in international law which has not been decided by any relevant legal authority, and it is not clear what such an authority might be. Perhaps a "claim of legal right" is a claim made by a given jurisdiction that it has a right to legislate for a specific region, even though the claim is not accepted by other claimants. In that case, it seems as if the claim itself is a political or moral claim, rather than a legal claim, and hence that the Supreme Court decision differs rhetorically, rather than legally, from the earlier decisions in Boland, Crotty, and Russell v Fanning.

\section{The Good Friday Agreement, 1998}

The limited jurisprudence of Articles 2 and 3 will be radically revised since the provisions of the Good Friday Agreement were implemented and the Constitution was amended accordingly. ${ }^{33}$ However, the amended Articles continue to appeal to the reality of "the Irish nation" [náisiún na hÉireann] as a basis for the new provisions and, to that extent, continue to reflect a nationalist philosophy, even if it is amended in significant ways.

The amendment to Article 2 explicitly extends membership of the nation to everyone born in the island of Ireland and to naturalised citizens.

"It is the entitlement and birthright of every person born in the island of Ireland, . . . to be part of the Irish nation. That is also the entitlement of all persons otherwise qualified in accordance with law to be citizens of Ireland."

32 McGimpsey v Ireland [1990] IR 110, at 119.

33 Following the Nineteenth Amendment to the Constitution Act 1998 [signed into law on June 3, 1998] the amended Articles 2 and 3 were incorporated, provisionally, into Article 29. The latter specifies that the amended Articles 2 and 3 will replace the 1937 version of the same Articles, if a declaration is made by the Irish government within twelve months, or such longer period as may be determined by law, that the State has become obliged to implement the Agreement. Thus the amendments to Articles 2 and 3 were included in the amended Article 29, awaiting a final decision either to delete them from the Constitution or to relocate them as replacements for Articles 2 and 3. The relevant declaration was made by the Irish Government on December 2, 1999. The Constitution was thereby amended. The unique mechanism adopted for the proposed amendments is described in O'Donnell, "Constitutional Background to and Aspects of the Good Friday Agreement," 1999 (50) NILQ, 76. 
This has the merit of recognising that membership of the Irish nation is open to all those born on the island of Ireland, irrespective of their cultural, religious or political traditions.

Nonetheless it is important, at this stage, to emphasise a distinction between what was adopted as amendments to the Irish Constitution, and what is otherwise included in the Belfast Agreement. The Agreement acknowledges that "the present wish of a majority of the people of Northern Ireland. . . is to maintain the Union," and that it is "the birthright of all the people of Northern Ireland to identify themselves. . . as Irish or British, or both, as they may so choose, and accordingly. . . to hold both British and Irish citizenship." ${ }^{34}$ In this sense, the extension of membership of the Irish nation cannot deprive those who so choose of their British nationality. By conceding the right of people in Northern Ireland to hold both British and Irish citizenship, and by recognising that the relevant people have a choice, the Agreement implies that membership of one nation may overlap with that of another. Whether or not this concession about dual membership in the Agreement modifies the concept of Irish nationality in the Constitution remains an open question.

The question of consent to membership of the Irish nation is explicitly raised in the amended version of Article 3:

"It is the firm will of the Irish nation, in harmony and friendship, to unite all the people who share the territory of the island of Ireland, in all the diversity of their identities and traditions, recognising that a united Ireland shall be brought about only by peaceful means with the consent of a majority of the people, democratically expressed, in both jurisdictions in the island. Until then, the laws enacted by the Parliament established by this Constitution shall have the like area and extent of application as the laws. . . etc. [of the Irish Free State]."

This amendment, once implemented, ${ }^{35}$ resolves the remaining ambiguity about the "claim of legal right" introduced by the McGimpsey decision and removes the claim from the Constitution that the Oireachtas may legislate for Northern Ireland. It also has the merit of acknowledging that the people on the island of Ireland have distinct cultural identities, and that the unification of the island is a political objective that may be pursued only within limits set by the democratically expressed consent of the people in each jurisdiction. All this must be welcomed as removing the constitutional ambiguity of the 1937 text and as recognising the role of democratic consent in political changes.

But underlying the amendments to Articles 2 and 3 , there remains a commitment to at least a modified version of the nationalism which inspired the original text. This is apparent insofar as the amended Constitution continues to assume the basic principle identified by Gellner, namely the

34 Agreement Reached in the Multi-Party Negotiations, pp 33, 34. Cf Annex 2, Declaration on the Provisions of Paragraph (vi) of Article 1 in relationship to Citizenship, p 35, in which the phrase "the people of Northern Ireland" is defined.

35 See note 33 above. 
ideal of congruence between nation and state. The logic of nationalism implies that the Irish nation has a right to a separate state that coincides with "the national territory"; since there are many people living in Northern Ireland who prefer to remain British citizens, and since one can assume that they will not agree to emigrate elsewhere, the only way of realising a noncoercive congruence between nation and state, in a united Ireland, is by extending membership of the Irish nation to all those born in Northern Ireland. In other words the underlying philosophy is: firstly, to claim the whole island as the appropriate geographical region for the Irish nation and then to accept, as the unavoidable price of making the nation and state coincide, that all current residents of the island must be admitted to membership of the Irish nation. The argument here is not that the Good Friday Agreement compromises the British nationality of those born in Northern Ireland and who choose to remain British citizens. It does not. However, only some provisions of the Agreement have been included in the Irish Constitution, ${ }^{36}$ and those sections are consistent with the nationalist political aspirations of the original text. This amounts to reading the Agreement as a compromise document in which both the British and Irish governments set out their political objectives and each recognises the legitimacy of the other's aspirations. Apart from the principle of consent, which precludes coercive methods for realising political objectives, the aspirations expressed by the amended Irish Constitution remain fundamentally nationalist.

Thus, consistent with its underlying principles, Irish nationalism copes with radical cultural diversity either by excluding those who do not fit neatly within its parameters (the 1937 solution), or by including them without adequately recognising their distinctness (the Belfast Agreement solution). In either solution, the question left unasked is about the rationale for continuing to divide people living on the island of Ireland, in the late twentieth century, into distinct nations.

\section{PART III - NATIONALITY AND MULTICULTURALISM}

One of the implications of recent work on nationalism and multiculturalism is that our nationality is not something given, fixed or inherited in the way that other features of our reality are to a greater or less extent unmodifiable. Nationality is a cultural construct of a very complex kind and is open to use or exploitation for a variety of disparate political, economic or social ends. These two points - the malleability of nationality and its availability for exploitation - are inextricably linked. Many of those who appeal to their nationality to justify political ends do so as if the former were both given and fixed, and as if it implied the political conclusion to which they themselves are favourably disposed. But the logic of the argument may run as easily in the opposite direction. A group of people may first decide on a given political end, and then intentionally fashion the kind of national consciousness that is most conducive to realising that end. For example, as already indicated above, state-building is usually facilitated by a simultaneous fostering of a shared national consciousness. Hence the

36 Article 29 has also been amended so that the State may become bound to honour the whole Agreement as an international treaty. 
cultivation of a particular national consciousness may be either a means or an end. Once it is acknowledged that both political objectives and nationality are equally subject to modification, and that neither one provides a secure, unchangeable basis for the other, we can move logically within their circular interconnection by questioning either one of the mutually dependent pair.

It is beyond dispute that the framing of the Constitution in 1937 was motivated by a very specific nationalist agenda, and that the resulting document bears the hallmarks of its historical conception. However, from the perspective of current political philosophy, the nationalist philosophy which inspired many of its provisions is open to question. This questioning cannot be avoided simply by appealing to current constitutional arrangements in the Republic of Ireland. One cannot establish a nation by means of a referendum, even if it is approved by a much larger majority than those who voted for Bunreacht na hEireann (in 1937) or in support of the Good Friday Agreement amendments (in 1998). Instead, the Constitution presupposes the existence of the reality called the "Irish nation" and appeals to it as a justification for the basic laws it brings into force. The circularity mentioned above between nationalism and political objectives is not logically "vicious", as long as we realise that there are no fixed foundations, historical or legal, which preclude raising certain kinds of question at this point in time. But it would be circular in an illogical sense if one hoped to justify the existence of a particular type of nation by pointing to a constitution which evidently presupposes its prior existence. Thus, whether or not there exists a reality called "the Irish nation" cannot be decided by reference to the text of the Constitution.

It follows from what has been said so far - or, more accurately, from contributions over the past two decades to our understanding of nationalism - that the fundamental question facing any community of people, when they address questions about their nationality, is: what kind of nationalism [if any] do they want, and how are they most likely to succeed in cultivating it? This is not a question that applies only to those who are called "nationalists". Many other residents of the island of Ireland, who might shudder at the thought, are more committed to a form of nationalism than they are likely to admit. In particular, those who call themselves "Unionists" in Northern Ireland may be as dependent on nationalism [in their case, on their conception of British nationality] as their so-called Nationalist neighbours. Thus the question about what kind of nationalism is desirable is one that can usefully be entertained by anyone living on the island of Ireland or, further afield, by anyone living in the United Kingdom or elsewhere. ${ }^{37}$

\section{Inclusive or Exclusive Nationality?}

It goes without saying that nationality, by its nature, divides people into distinct groups. For any particular nation, some people are classified as members and others are not. The motivation for raising national consciousness and making such divisions may be benign, and it may be

37 Recent expressions of Scottish nationalism are relevant here. For one way in which Scottish nationalism, as a cultural phenomenon, can be expressed within the constitutional structures of the United Kingdom, see MacCormick, "Liberal Nationalism and Self-Determination," Clarke and Jones, eds, 65. 


\section{Northern Ireland Legal Quarterly [Vol. 51, No. 1]}

supported initially as a means of uniting people into a viable political community. But there is no known nationality that includes all the people of the world. To describe oneself as having a given nationality, or as belonging to a particular nation, is automatically to exclude other people from membership of the same group. This is not to say that one may not be a member of more than one nation; that is certainly still possible, and in that case there is an overlap between national groups and their respective memberships. But if there were no distinction between members and nonmembers of a given nation, then there would be no point in having such a national identity in the first place. National identity or affiliation divides the people of the world into distinct groups, which may or may not overlap to some extent.

This system of division does not assume that the criteria for membership of a given nation must be clear, explicit or sharp. It is much more likely that the line of demarcation between members and non-members will be unclear, unarticulated or fuzzy. ${ }^{38}$ It is also likely, as indicated above, that members will satisfy the criteria for membership of a nation to a greater or lesser extent, and that some members will be marginal both in satisfying the conditions and in their consciousness of belonging to a particular national group.

Thus national identity is a cultural construct with vague and possibly overlapping boundaries, and the relative sharpness of the boundaries is likely to depend on the political objectives for which the national identity in question is cultivated.

Nation-building exercises typically involve attempts to impose a linguistic and cultural uniformity on all the disparate groups who are to be included in a nation-state. In some cases, evidently, such a programme is doomed to failure from the outset - as in Switzerland or Belgium - and those who hope to unify distinct linguistic and cultural groups into a single political entity must be willing to tolerate more inclusive criteria for membership. If one reviews the nationalist philosophy which inspired the separatist political movements in Ireland in the nineteenth and twentieth centuries, it is evident that anti-colonialism was one of its principal motivating factors. Consequently those who were associated with British colonial policy in Ireland were least likely to be included as members of the newly defined Irish nation. Their distinctive cultural characteristics were Protestantism (as Linda Colley has shown in her historical analysis of British nationalism), speaking English rather than Irish, and, in general, sharing the cultural traditions which were distinctive of Britain. In the political confrontations that resulted from this anti-colonial movement, it seems almost inevitable in retrospect that Irish identity was defined in opposition to British identity and

38 Cf Lord Simon in Ealing London Borough Council v Race Relations Board [1972] AC 342, 362, in relation to sec 1 (1) of the 1968 Act: "This is rubbery and elusive language - understandably when the draftsman is dealing with so imprecise a concept as 'race' in its popular sense and endeavouring to leave no loophole for evasion." Despite the difficulties involved, the courts have found sufficient precision in the phrase "on the ground of colour, race or ethnic or national origins" to identify unlawful discrimination. 
that the Irish nation was defined, even if only implicitly, by reference to features which were most likely to distinguish it from British nationality.

Recent studies of nationalism also point to the extent to which an emerging national identity is likely to be projected back into the past, and to how this projection is assisted by what Renan famously described as "a shared amnesia, a collective forgetfulness" on the part of the relevant community. Thus the narrowness or exclusiveness of a particular nationality at a given historical period, initially promoted for immediate political objectives, is projected back into history and forward into the future. There is no natural or historical inevitability about this. The whole cultural construct is, as already indicated, partly a function of the current beliefs of the participants. We persuade ourselves about our distinctiveness or our national identity, and we construct a history (that is, another coherent set of beliefs) that supports our convictions about our national identity. But the coherence of both our nationalist and historical beliefs, and the political advantages that result from their adoption and dissemination, must eventually be evaluated in terms of the divisiveness they entail and the disadvantages they cause in the community.

When these general remarks are applied to Irish nationality, the conclusion they point to is that the concept of nationality which is pervasive in the Constitution is a cultural construct which emerged from the anti-colonial political struggles of the last three centuries; that there is nothing given, fixed or unchangeable in the relatively recent historical construction of "the Irish nation"; that the understanding of "the national language" and "the national territory" in 1937 was a function of a nationalist political philosophy that was prevalent at that time, rather than an uncontentious historical fact; and that the way in which Irish people (however they are to be identified) specify their nationality in the late twentieth century is not determined uniquely by our past, but is open to redefinition in virtue of our current beliefs about what we have in common. In particular, we can reinforce an exclusive and divisive concept of our national identity which marginalises or excludes many people in contemporary Irish society. Alternatively, we can recon-ceptualise our nationality in a less exclusive way, so that it leaves open membership of the "nation" to those who are less enamoured of the myths which supported the development of one form of Irish national consciousness in the early decades of the twentieth century.

\section{Why Change?}

Why should the people of a given geographical region re-think their national identity? Why should they re-write their history - that is, the account of their past to which they have become accustomed - and perhaps, in doing so, reevaluate the honorific status of those who engaged in the "heroic and unremitting struggle" for the international recognition of Ireland as a distinct nation? Is it not an extreme and implausible form of revisionism not only to re-evaluate the past but also to attempt to change our identity by modifying our current beliefs about who we are?

The answer to the first question, in summary form, is easy: because justice demands it. Justice demands, in a region that includes individuals with diverse cultural identities, that their cultural diversity should be acknowledged and that no group should be allowed to impose its culture, by 
exclusion or enforced inclusion, on others. This is an insight that has emerged relatively recently in discussions of multiculturalism and in what Charles Taylor has called the "politics of recognition". ${ }^{39}$ Evidently, major questions may be raised about what counts as a legitimate part of one's culture, and about the extent to which cultural practices that compromise the rights of individuals should be legally recognised in a modern democracy. None of these issues is addressed here. ${ }^{40}$ But one could at least begin by recognising that linguistic diversity is a characteristic feature of many modern democracies, and that it is unnecessarily coercive of individuals to require all co-nationals to speak the same language[s]. Thus the Irish Constitution might begin by recognising both Irish and English as equally official and national languages, so that citizens are free to carry out their public duties by using either one.

Once the question is raised about linguistic prerequisites for national membership, the apparent necessity of other criteria may also be queried. It may not be necessary, in order to be genuinely Irish, to share the enthusiasm of many citizens for the games sponsored by the Gaelic Athletic Association, to share the religious beliefs of a majority of citizens in the Republic, or to enjoy the music and dance that are typically classified as "Irish". As the list gets longer, it might seem as if we have embarked on an extremely slippery slope [in the logical sense], and that there remain no criteria at all by which to distinguish those who properly belong to the Irish nation. However, the danger threatend by a slippery slope is a sufficient reason not to ask questions only for those whose insecurity outweighs the logic of the argument. The guiding principle remains, despite the danger of slippage: justice demands that our concept of the nation be catholic enough to include those who were born in Ireland, but whose religious and cultural affiliations alienate them from the hegemonic and exclusive nationalism of one dominant, politically active group.

Should we also re-write history? This question may sometimes be asked in a rhetorical style, as if merely asking the quesion suggests an obvious negative answer. However, it is an extremely simplistic view of history, as a story about our past, either to think that it has already been written perfectly by others, or that there is no selection made in the events discussed or the interpretation of them that is generally endorsed. Any history is a theory about the past. Recent work in philosophy of science has shown the extent to which, even in the sciences, our descriptions of what are usually called "facts" are theory-laden because of the conceptual framework used to describe them. ${ }^{41}$ If physics is theory-laden, then a fortiori so is history. There is no question, then, about whether or not we should re-write history. We can either repeat what earlier historians have written - in which case we are not doing history at all - or we can put our minds to the interpretation of the past in the light of the best and most recent scholarship available. Doing history is, of necessity, re-writing the story of the past.

Of course, neither reconceptualising our national identity nor re-writing our history is remotely as easy as the arguments that support their necessity,

39 Gutmann, ed. Multiculturalism and the 'Politics of Recognition' (Press, 1992).

40 See Barry, 'The Limits of Cultural Politics,' in Clarke and Jones, ed, p 127.

41 See Rorty, Philosophy and Social Hope (1999), p 175. 
because the effort involved in either case is not exclusively intellectual. Both are inhibited by interests that are more deep-seated and less explicitly acknowledged than the logic of any argument. However, we can begin the task by questioning the justification offered by proponents of exclusive nationalism, because their justification is articulated in the world of ideas and of speech, rather than in the murky, intractable underworld of competing political and economic interests.

What, then, for the future? The Irish Constitution, even when amended as a result of the Good Friday Agreement, ${ }^{42}$ is fundamentally inspired by a nationalist ideology. It assumes the existence of a people, náisiún na hÉireann, which is distinct from other European peoples with whom we share much of our history and our culture. It attributes to this people a national language which is not widely spoken among its members. It claims for this people a right to self-government, and assumes that its political jurisdiction should coincide with the island of Ireland as its rightful "national territory." Following the Good Friday Agreement, the Constitution has been amended to acknowledge that membership of the Irish nation is open to many people whose religious, cultural and political traditions differ significantly from those whose philosophy inspired the text of 1937. By accepting the principle of consent, the amended Constitution also modifies the measures that may legitimately be used to realise the nationalist goal. However, it changes little in the goal itself. More fundamentally, it changes little in the way in which we conceptualise the competing claims of members of a multicultural population.

As already mentioned above, this is not a comment about the Good Friday Agreement, but about the kind of nationalism which survives even in an amended version of Bunreacht na hÉireann. The Belfast Agreement represents an evidently welcome compromise between competing political objectives. The focus here is on analysing the political philosophy that is presupposed in one [or both?] of those objectives, namely, in nationalism. Thus, despite the parallel statements of the rights and duties of the contending traditions, and of the common ground agreed by both, there remains a question about the ways in which the disputing parties conceptualise the realities about which they disagree.

The political landscape could be changed almost beyond recognition by revisions in that underlying political philosophy. This would imply that we begin from the reality of individuals who currently live on the island of Ireland; that we acknowledge the extent of their religious, cultural and political diversity; that we accept the principle of democratic consent; and that, once these realities have been acknowledged, we consider the feasibility of different political structures that would respect the diversity of the people who live on the island. In particular, it would involve deferring assumptions about the nationality of different groups until their equality as citizens is first established, and surrendering the fundamental principle of nationalism identified by Gellner, namely, that political units or structures must be congruent with the distribution of national groups. Hence the emphasis on parity of esteem. Evidently, such an inversion of the logic of nationalism is feasible - even in an ideal political community - only if the cultural and civil

42 See above, note 33 . 
rights of different groups are respected equally. An oppressed group in any society is likely to develop a distinct national consciousness as a means of developing the kind of solidarity that is needed, among the oppressed, to assert their rights.

In a less than ideal community, the new millennium beckons us to question the nationalist assumptions by which we have classified and divided from each other the people who live on the island of Ireland. We could try thinking first about citizens, about their rights and interests, and only later consider the various "imagined communities" to which they belong. In summary, to conceptualise the history and political realities of the island of Ireland in terms of national affiliations is to assume a framework which classifies citizens in terms of incompatible nationalities. ${ }^{43}$ If this classification includes the Gellner thesis, implicitly or otherwise, to the effect that a nation has a right to exclusive sovereignty over its national territory, the apparent insolubility of the constitutional issues that beset the island is logically implied by the very terms in which they are conceived, that is, in incompatible claims by different communities to different national identities, and in claims to exclusive jurisdiction over the same geographical region which result from competing nationalities. Any hope of progress presupposes an alternative conceptualisation. Minimally, it requires a surrender of the claim that a distinct national group must have exclusive political control over a geographical region identified as "the national territory", even when it includes a significant population which, by its own choice, claims a different nationality to that of the majority. Cultural nationalism in this sense, that is, nationalism without exclusive territorial claims, is compatible with a wide range of political structures which respect and accommodate multicultural citizens.

43 If all residents of Northern Ireland were willing to think of themselves as both British and Irish, then their nationalities would not be incompatible. But as long as some such residents see the implications of Irish nationality as accepting the territorial aspiration of Irish Nationalists (which is made explicit by the Gellner thesis), then these two nationalities are, for them, incompatible. 